\title{
ENERGY CONSUMPTION AND SELECTED PHYSICAL PROPERTIES OF CORN-OAT INSTANT GRUELS UNDER SPECIFIC EXTRUDER CONFIGURATIONS
}

\author{
Magdalena KRĘCISZ ${ }^{1}$, Agnieszka WÓJTOWICZ1 ${ }^{1}$, Anna ONISZCZUK ${ }^{2}$ \\ ${ }^{1}$ University of Life Sciences in Lublin, Department of Thermal Technology and Food Process Engineering, \\ POLAND \\ ${ }^{2}$ Medical University of Lublin, Department of Inorganic Chemistry, POLAND \\ E-mail of corresponding author: agnieszka.wojtowicz@up.lublin.pl
}

Keywords: corn, oat, physical properties, energy consumption, process management

\begin{abstract}
The extrusion-cooking technique was used for the processing of corn-oat blends with three various screw configurations. The procedure involved the assessment of the effects of the processing conditions on energy consumption. The initial moisture level ranged from 16 to $22 \%$ and the screw speed applied during the processing varied from 80 to $120 \mathrm{rpm}$. Corn-oat gruels were tested for water absorption and bulk density. A significant effect was reported of the initial moisture and screw speed on energy demand as well as on the physical properties of extrudates. The use of the shortest version of the extruder requires more energy than with the longer ones. Corn-oat instant gruels processed with an elongated barrel showed lower water absorption compared with the shorter one. The most important parameter having an influence on the product quality was the initial moisture content of extruded blends. The obtained results can be helpful in management of sustainable settings, low-energy processing conditions and the proper characteristics of extruded instant corn-oat gruels.
\end{abstract}

\section{INTRODUCTION}

Among the many natural raw materials enriching the production of functional foods, more and more interest is attached to pseudo-cereals, such as oat (Avena sativa), which is characterized by the unique health and dietary values and is considered a cereal crop of the $21^{\text {st }}$ century. Oat is a cereal used most often for feed purposes: only a small amount of it is intended for consumption. Oat, compared to other cereals, stands out because of its specific chemical composition and its nutrients influence the production of fortified and fitness foods suitable for human nutrition (Butt et al. 2008). Oat has high levels of non-starch polysaccharides, including pentosans and $\beta$-glucans, which are important constituents of dietary fiber, and less saccharides, in particular starch, than other cereals (Kawka 2010). This grain is a source of B vitamins, minerals, dietary fiber (soluble and insoluble) and antioxidants with the ability to remove free radicals, able to stimulate the immune system to reduce the risk of hyperinsulinemia, hyperglycemia, obesity, hypertension, coronary heart disease, and contribute to the lowering of total cholesterol (Berski and Gambuś 2014, Singh et al. 2013). Fat contained in oat has a positive ratio of unsaturated to saturated fatty acids (Zhou et al. 1999), though it could hamper processing. The extrusion-cooking technology is sustainable method used for the production of a wide range of cereal products: crisps, cereals, batteries, flat bread, pellets, texturized proteins, baby food, confectionery (chewing gum, sweets), animal feed and specialty products, e.g. modified starch or functional components. By applying pressure, specific temperature and shearing, the material is mixed, cooked, plasticized, and expanded. Following such treatment, intense changes occur in the chemical and physical properties of the materials, their results depending mainly on the extruder configuration and extrusion conditions (Mościcki et al. 2007). These technical and technological aspects of extrusion could also influence energy consumption during the processing and the degree of sustainability of this method compared with other food processing techniques. 


\section{MATERIALS AND METHODS}

Corn grits (purchased from Lubella Sp. z o.o. Sp. K., Lublin, Poland) and oat flour (Metvit S.A., Warszawa, Poland) were used as the basic raw material in the amount of $25 \%$ of the blend. The materials were mixed with a ribbon mixer and moistened with a specific volume of water (Wójtowicz, 2008) to obtain the moisture content before the extrusion-cooking at the level of 16, 18, 20 and $22 \%$. The extrusion-cooking was carried out by means of the modified single screw extruder TS-45 (Metalchem, Gliwice, Poland) with the L/D configurations of $12: 1,16: 1$ and $18: 1$, at the temperature ranged $120-135^{\circ} \mathrm{C}$, with a forming die of $3 \mathrm{~mm}$ and at the screw speed ranged $80-120 \mathrm{rpm}$. The extrudates were dried below $10 \%$ of the moisture content and ground with the laboratory grinder LMN10 (TestChem, Radlin, Poland) to a granulation below $1 \mathrm{~mm}$. Power consumption, expressed as SME (Specific Mechanical Energy), was determined at each change of the rotational speed of the screw during the extrusion-cooking of mixtures with the different initial moisture content in raw materials. The engine load and process efficiency of each test were converted into SME $\left(\mathrm{kWh} \cdot \mathrm{kg}^{-1}\right)$ as proposed by Kręcisz (2016), taking into account the extruder working parameters. The water absorption index (WAI) was determined through centrifugation (Bouasla et al. 2017, Wójtowicz and Mościcki 2014) for each sample in three replications as the amount of absorbed water $(\mathrm{g})$ per $\mathrm{g}$ of a dry sample. Bulk density was assessed in five replications as a mass $(\mathrm{kg})$ of specific sample volume $\left(\mathrm{m}^{3}\right)$ using a measuring cylinder filled gently with corn-oat gruels (Wójtowicz et al. 2013). The obtained results were tested with the bidirectional ANOVA analysis of variance using the Statistica software (version 10.0, USA). The first factor was moisture (M) and the second was the screw speed (S). The RSM (response surface methodology) was used for fitting the polynomial models $\left(Y=b_{0}+b_{1} X_{1}+b_{2} X_{2}+b_{11} X_{12}+b_{12} X_{1} X_{2}+b_{22} X_{22}\right.$, where $X_{1}$ was the moisture content and $X_{2}$ was the screw speed applied), and quadratic equations of the tested characteristics were designated depending on the variables used in the experiment (Table 1).

Table 1. Adequacy of two-variable model used for the tested characteristics of instant corn-oat gruels.

\begin{tabular}{|c|c|c|}
\hline Parameter & Fitted model & $\mathrm{R}^{2}$ \\
\hline \multicolumn{3}{|c|}{$\mathrm{L} / \mathrm{D}=12: 1$} \\
\hline SME $\left(\mathrm{kWh}_{\mathrm{kg}}{ }^{-1}\right)$ & $\mathrm{SME}=-0.39+0.07 \mathrm{M}-0.003 \mathrm{~S}-0.002 \mathrm{M}^{2}+0.0001 \mathrm{MS}+6.03 \mathrm{E}-6 \mathrm{~S}^{2}$ & 0.64 \\
\hline WAI $\left(g \cdot g^{-1}\right)$ & $\mathrm{WAI}=-15.52+3.32 \mathrm{M}-0.18 \mathrm{~S}-0.11 \mathrm{M}^{2}+0.009 \mathrm{MS}+1.6 \mathrm{E}-5 \mathrm{~S}^{2}$ & 0.87 \\
\hline$\rho_{\mathrm{b}}\left(\mathrm{kg} \cdot \mathrm{m}^{-3}\right)$ & $\rho_{\mathrm{b}}=2476.05-262.91 \mathrm{M}-1.76 \mathrm{~S}+8.02 \mathrm{M}^{2}+0.073 \mathrm{MS}+0.004 \mathrm{~S}^{2}$ & 0.93 \\
\hline \multicolumn{3}{|c|}{$\mathrm{L} / \mathrm{D}=16: 1$} \\
\hline SME $\left(\mathrm{kWh}_{\mathrm{kg}}{ }^{-1}\right)$ & $\mathrm{SME}=-1.05+0.10 \mathrm{M}+0.004 \mathrm{~S}-0.003 \mathrm{M}^{2}-3.47 \mathrm{E}-5 \mathrm{MS}-1.69 \mathrm{E}-5 \mathrm{~S}^{2}$ & 0.64 \\
\hline WAI $\left(g \cdot g^{-1}\right)$ & $\mathrm{WAI}=3.53+0.18 \mathrm{M}+0.01 \mathrm{~S}+0.002 \mathrm{M}^{2}-0.004 \mathrm{MS}+0.0002 \mathrm{~S}^{2}$ & 0.55 \\
\hline$\rho_{\mathrm{b}}\left(\mathrm{kg} \cdot \mathrm{m}^{-3}\right)$ & $\rho_{b}=-898.56+169.32 \mathrm{M}-9.65 \mathrm{~S}-4.61 \mathrm{M}^{2}+0.36 \mathrm{MS}+0.017 \mathrm{~S}^{2}$ & 0.86 \\
\hline \multicolumn{3}{|c|}{$\mathrm{L} / \mathrm{D}=18: 1$} \\
\hline $\mathrm{SME}\left(\mathrm{kWh} \cdot \mathrm{kg}^{-1}\right)$ & $\mathrm{SME}=-0.26+0.06 \mathrm{M}-0.004 \mathrm{~S}-0.002 \mathrm{M}^{2}+0.0001 \mathrm{MS}+9.09 \mathrm{E}-6 \mathrm{~S}^{2}$ & 0.68 \\
\hline WAI $\left(g \cdot g^{-1}\right)$ & $\mathrm{WAI}=5.36+0.39 \mathrm{M}-0.09 \mathrm{~S}-0.01 \mathrm{M}^{2}+0.002 \mathrm{MS}+0.0003 \mathrm{~S}^{2}$ & 0.10 \\
\hline$\rho_{\mathrm{b}}\left(\mathrm{kg} \cdot \mathrm{m}^{-3}\right)$ & $\rho_{b}=2125.81-204.27 \mathrm{M}-2.92 \mathrm{~S}+5.22 \mathrm{M}^{2}+0.41 \mathrm{MS}-0.03 \mathrm{~S}^{2}$ & 0.72 \\
\hline
\end{tabular}




\section{RESULTS AND DISCUSSION}

The extrusion-cooking of corn gruels with the addition of oat flour in the amount of $25 \%$ with the L/D configuration of 12:1 demonstrated the specific mechanical energy consumption (SME) within 0.064-0.122 $\mathrm{kWh} \mathrm{kg}^{-1}$ (Fig. 1a). The SME values depended mainly on the moisture content $\left(\mathrm{p}_{\text {-value }}=0.000\right)$. Along with the increase of the moisture content in the mixture, greater SME values were reported, which may be also seen in the results presented by Kręcisz (2016), where an increase in the moisture content increased the SME value in corn instant gruels. Some increase of SME with higher rpm was observed for the extrudates with 18 and $20 \%$ of initial moisture ( $\left.\mathrm{p}_{\text {-value }}=0.064\right)$.
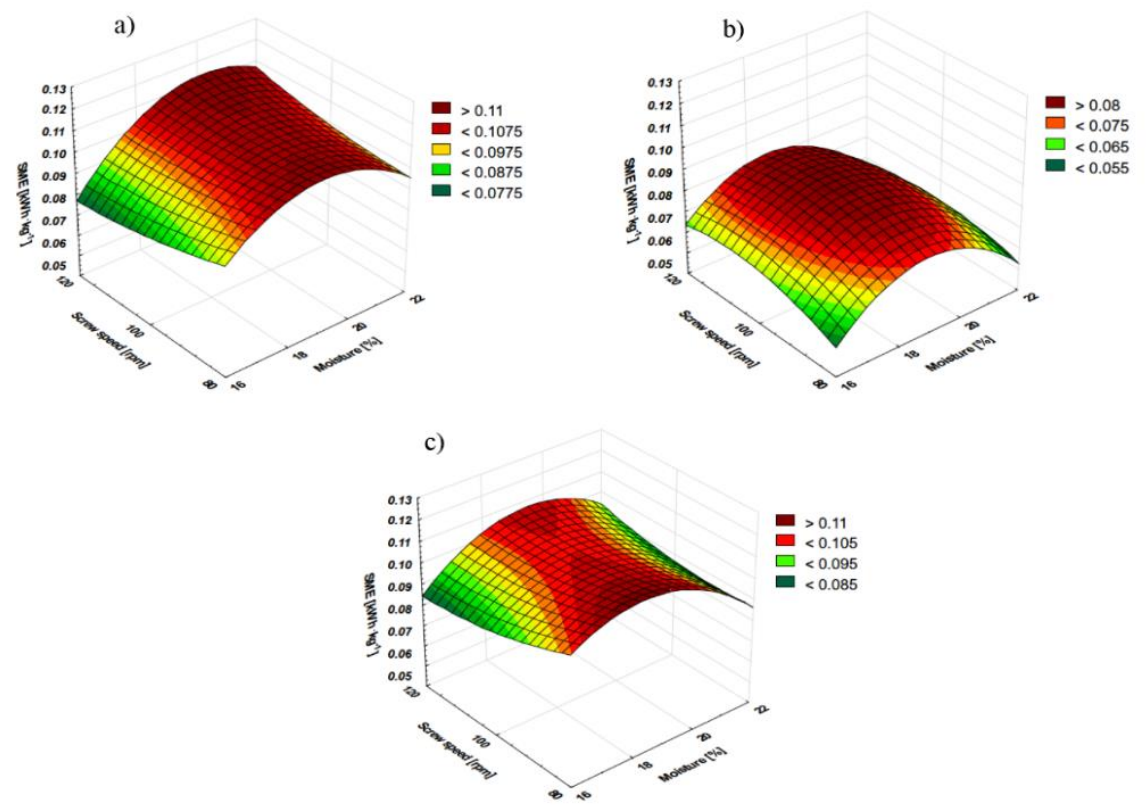

Fig. 1. SME of corn-oat instant gruels processed with various L/D configurations depending on moisture and the screw speed applied: a) 12:1, b) 16:1, c) $18: 1$.

When the extrusion-cooking was done using the L/D configuration of 16:1, the SME values increased along with the rise in moisture up to $18 \%$; yet, a further increase of moisture of up to $22 \%$ resulted in a significant decrease of the SME values ( $\mathrm{p}_{\text {-value }}=0.000$ ). The influence of the screw speed on the SME values was also significant ( $\left.p_{\text {-value }}=0.026\right)$. Based on the test results, it can be concluded that a higher screw speed (up to $100 \mathrm{rpm}$ ) resulted in a significant increase of SME consumption. Higher rpm applied during the processing resulted in the lower SME values, especially if the initial moisture content of blends was 16 and 18\% (Fig. 1b). During the extrusion-cooking of corn-oat blends with the L/D configuration of 16:1, a decrease in energy consumption $\left(0.048-0.099 \mathrm{kWh}^{-1}\right)$ was observed compared with $\mathrm{L} / \mathrm{D}=12: 1$. The results with $\mathrm{L} / \mathrm{D}=18: 1$ demonstrated that the increase of blend moisture of up to $20 \%$ caused the increased SME (Fig. 1c). It was found that the values of SME varied between 0.081 and $0.118 \mathrm{kWh} \cdot \mathrm{kg}^{-1}$ depending on the applied processing parameters. Changes in SME significantly depended on the moisture of raw materials $\left(\mathrm{p}_{\text {-value }}=0.000\right)$ and the screw speed $\left(\mathrm{p}_{\text {-value }}=0.006\right)$. The higher moisture content resulted in the lower SME values of instant gruels. The results show a significant impact of the screw rational speed on the SME value as the increased rpm caused higher energy consumption up to $100 \mathrm{rpm}$. The higher screw speed caused the decrease of specific mechanical energy consumption during the extrusion-cooking process of corn-oat gruels. Similar results were reported for SME of corn extrudates (Kręcisz 2016) and wheat 
and spelt flour extrudates (Wójtowicz and Juśko 2012). Water absorption is also relevant in the treatment intensity during the extrusion-cooking (Bouasla et al. 2017). The WAI of instant gruels based on corn and oat reached the values from 4.21 to $6.02 \mathrm{~g}^{-1} \mathrm{~g}^{-1}$ if the shortest $\mathrm{L} / \mathrm{D}=12: 1$ configuration was applied for the processing (Fig. 2a). The WAI values were much higher than those presented for elongated extruder configurations and indicating more intensive treatment of corn-oat blends. The moisture content of the raw materials had a significant effect $\left(\mathrm{p}_{\text {-value }}=0.000\right)$ on the water absorption results. A higher moisture content level lowered the WAI of extrudates. The screw speed applied had no significant effect on the water absorption results $\left(\mathrm{p}_{\text {-value }}=0.064\right)$.
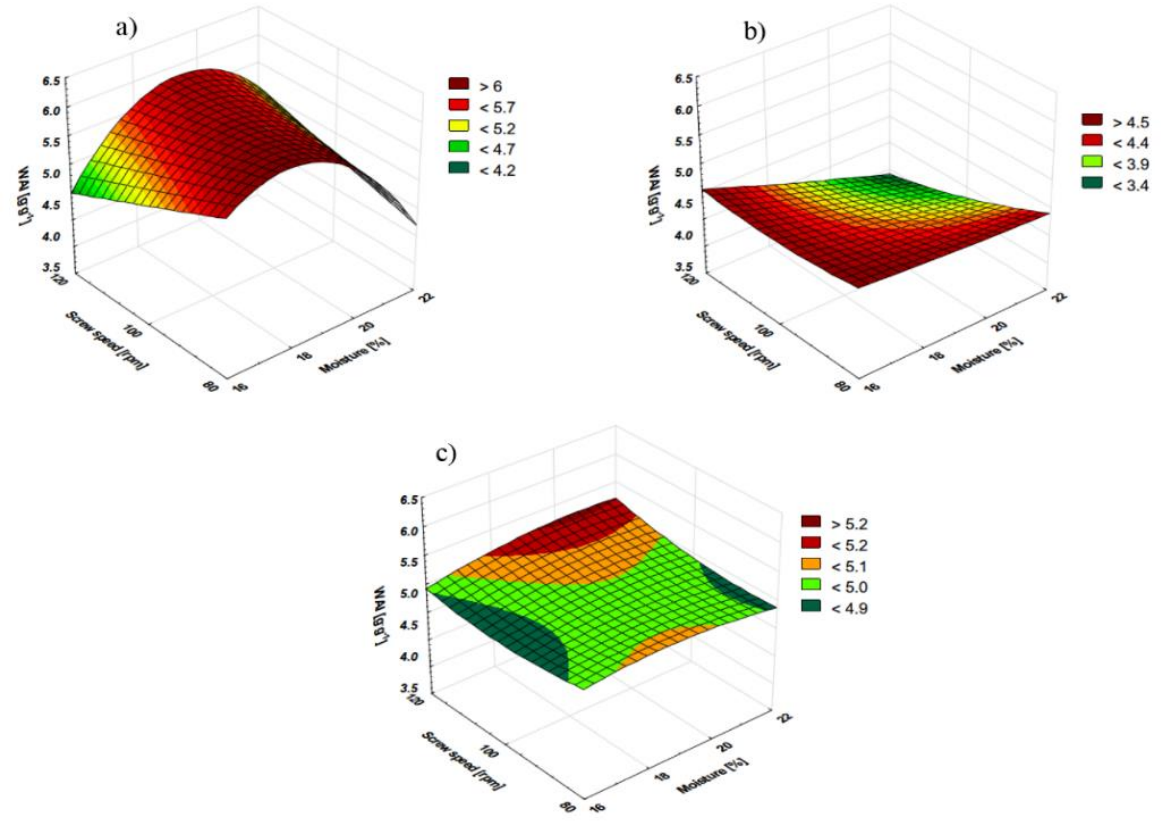

Fig. 2. The WAI of corn-oat instant gruels processed with various L/D configurations depending on moisture and the screw speed applied: a) 12:1, b) 16:1, c) 18:1.

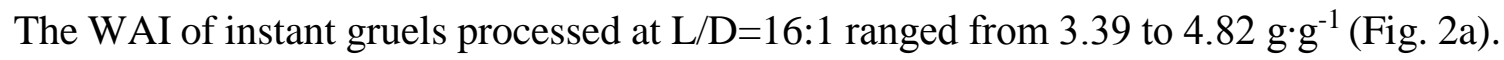
The range of the WAI reported by other authors depends on the raw materials and processing conditions used and, for example, varied from 5.58 to $6.38 \mathrm{~g} \mathrm{~g}^{-1}$ for gluten-free extrudates based on 75:25 corn-rice blends (Kręcisz and Wójtowicz 2017). This time the moisture content $\left(\mathrm{p}_{\text {-value }}=0.769\right)$ and the screw speed applied $\left(\mathrm{p}_{\text {-value }}=0.861\right)$ had no significant effect on the WAI. The results presented in Fig. $2 \mathrm{c}$ for $\mathrm{L} / \mathrm{D}=18: 1$ showed that the highest water absorption was seen in instant gruels processed at $18 \%$ of the initial moisture content at $100 \mathrm{rpm}$. The WAI values of instant gruels extruded with the longest barrel configuration ranged from 4.50 to $5.7 \mathrm{~g} \cdot \mathrm{g}^{-1}$. The higher initial moisture content in corn-oat extrudates had no significant effect on the water absorption values ( $\mathrm{p}_{\text {-value }}=0.577$ ). The influence of screw speed on the WAI values was insignificant ( $\left.\mathrm{p}_{\text {-value }}=0.290\right)$. Bulk density evaluated for instant gruels processed with $L / D=12: 1$ ranged from 264.82 to $651.86 \mathrm{kgm}^{-3}$ (Fig. 3a). The higher moisture content in the recipe has a significant impact ( $\left.\mathrm{p}_{\text {-value }}=0.000\right)$ on the increased bulk density of extrudates. The results showed that the highest bulk density was measured for instant gruels with the highest moisture content. The effect of screw speed was not significant $\left(\mathrm{p}_{\text {-value }}=0.780\right)$. 

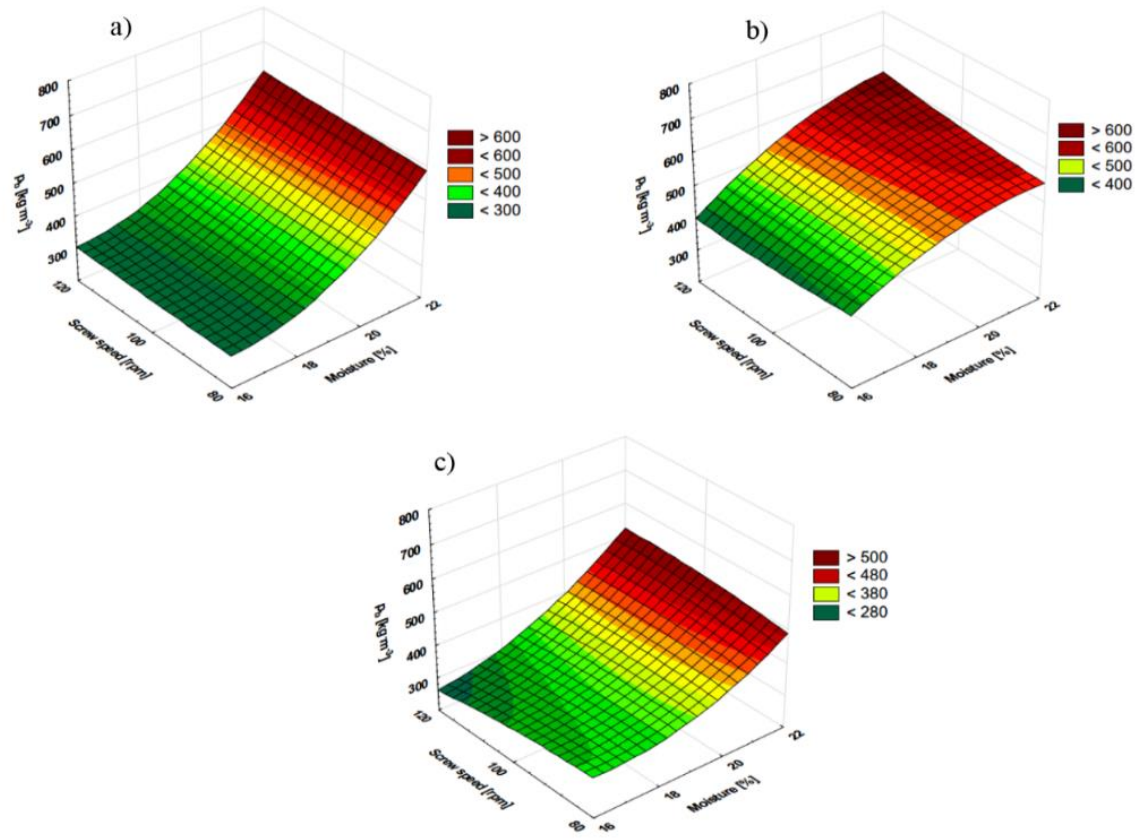

Fig. 3. Bulk density of corn-oat instant gruels processed with various L/D configurations depending on moisture and the screw speed applied: a) 12:1, b) 16:1, c) $18: 1$.

For corn-oat products processed at $\mathrm{L} / \mathrm{D}=16: 1$, the bulk density ranged from 392.91 to $612.76 \mathrm{kgm}^{-3}$ (Fig. 3b). The products processed with the high initial moisture content exhibited a denser and less porous structure, which has an impact on the higher values of bulk density. The increase in the initial moisture content in corn-oat blends showed a significant effect on the bulk density values ( $\mathrm{p}_{\text {-value }}=0.002$ ). Increased bulk density with an increase of rpm was observed for extrudates processed at $22 \%$ moisture content, but generally the screw speed had no significant effect on bulk density ( $p_{\text {-value }}=0.122$ ). When extrusion-cooking was done at $\mathrm{L} / \mathrm{D}=18: 1$, the bulk density values of instant corn-oat gruels ranged from 237.71 to $517.36 \mathrm{~kg} \cdot \mathrm{m}^{-3}$ (Fig. 3c). Kręcisz and Wójtowicz (2017) reported that the density values of corn-rice extrudates varied from 137.83 to 362.18 $\mathrm{kg} \cdot \mathrm{m}^{-3}$ depending on the extrusion temperature and moisture content. They also concluded that density rose along with higher moisture of the raw materials used. The moisture content of raw materials had a significant effect $\left(\mathrm{p}_{\text {-value }}=0.039\right)$ on bulk density, but the effect of the screw speed on the bulk density values was insignificant ( $\mathrm{p}_{\text {-value }}=0.798$ ).

\section{CONCLUSIONS}

The extrusion-cooking as sustainable process for the processing of corn-oat blends produced instant gruels resulted with various products characteristics. The level of initial moisture content and the rotational speed of the extruder screw used during the treatment had a significant effect on energy consumption and the tested properties of extruded corn-oat instant gruels. The processing of extrudates using various configurations of the single screw extruder yielded different properties of the extrudates. The research demonstrated a significant impact of the screw rotational speed on the SME value. The use of the elongated extruder configuration at $\mathrm{L} / \mathrm{D}=16: 1$ resulted in low SME, lowered WAI and increased density of instant gruels. The results showed the highest WAI in instant gruels processed at $\mathrm{L} / \mathrm{D}=12: 1$, which was the most intensive treatment of corn-oat blends. The most important parameter having an influence on the product quality was the initial moisture content of extruded blends. The discussed results should be helpful in selecting 
the adequate management and low-energy processing conditions in order to achieve the desired characteristics of extruded instant corn-oat gruels.

\section{REFERENCES}

Berski, W., \& Gambuś, H. (2014). Reologiczna charakterystyka układów trójskładnikowych : resztkowa mąka owsiana-sacharoza-woda. Acta Agrophysica, 21(1), 5-15.

Bouasla, A., Wójtowicz, A. \& Zidoune, M. (2017). Gluten-free precooked rice pasta enriched with legumes flours: Physical properties, texture, sensory attributes and microstructure. LWT-Food Science and Technology, 75, 569-77.

Butt, M., Tahir-Nadeem, M., Khan, M., Shabir, R., \& Butt, M., 2008. Oat: unique among the cereals. European Journal of Nutrition, 47, 68-79.

Kawka, A. (2010). Współczesne trendy w produkcji piekarskiej - wykorzystanie owsa i jęczmienia jako zbóż niechlebowych. Żywność. Nauka. Technologia, Jakość, 3(70), 25-43.

Klimek M., Mościcki L., Wójtowicz A., Oniszczuk T., Combrzyński M., \& Mitrus M., (2014). Dynamic viscosity of water and milk suspensions of extruded corn porridge. TEKA. Commission of Motorization and Energetics in Agriculture, 14(4), 37-40.

Kręcisz M., \& Wójtowicz A., (2017). Evaluation of selected properties of gluten-free instant gruels processed under various extrusion-cooking conditions. Acta Scientiarum Polonorum, Technologia Alimentaria, 16 (2), 135-147.

Kręcisz M., Wójtowicz A., \& Oniszczuk, A. (2015). Effect of selected parameters on process efficiency and energy consumption during the extrusion-cooking of corn-rice instant grits. Agriculture and Agricultural Science Procedia, 7, 139-145.

Kręcisz, M. (2016). Energy consumption during produciton of corn extrudates in relation to the process parameters. Agricultural Engineering, 20(2), 125-131.

Mościcki, L., Mitrus, M., \& Wójtowicz, A. (2007). Technika ekstruzji w przemyśle rolno spożywczym. PWRiL. Warszawa

Mościcki, L., Mitrus, M., Wójtowicz, A., Oniszczuk, T., Rejak, A., \& Janssen, L. (2012). Application of extrusion-cooking for processing of thermoplastic starch (TPS). Food Research International, 47(2), 291-299.

Singh, R., De, S., \& Belkheir, A. (2013). Avena sativa (oat), a potential neutraceutical and therapeutic agent: An overview. Critical Reviews in Food Science and Nutrition, 53, 126-144.

Wójtowicz, A. (2008). Wpływ nawilżania surowców oraz parametrów procesu ekstruzji na wybrane cechy zbożowych kaszek błyskawicznych. Acta Agrophysica, 11(2), 545-556.

Wójtowicz, A., \& Juśko, S. (2012). Wpływ typu mąki oraz prędkości wytłaczania na wydajność i energochłonność procesu oraz ekspandowanie ekstrudowanych makaronów błyskawicznych. Acta Scientiarum Polonorum, Technica Agraria, 11(3-4), 35-45.

Wójtowicz, A., Kolasa A., \& Mościcki, L. (2013). The influence of buckwheat addition on physical properties, texture and sensory characteristic of extruded corn snacks. Polish Journal of Food and Nutrition Science, 63, 4, 239-244.

Wójtowicz, A., \& Mościcki, M. (2014). Influence of legume type and addition level on quality characteristics, texture and microstructure of enriched precooked pasta. LWT-Food Science and Technology, $59,1175-1185$.

Zhou, M., Robards, K., Glennie-Holmes, M., \& Helliwell, S. (1999). Effects of oat lipids on groat meal pasting properties. Journal of the Science of Food and Agriculture, 79, 585-592. 